\title{
Reflections on Germany, the Legal Academy, and Social Engagement: An Interview with Richard Buxbaum
}

\author{
By \\ Laurel E. Fletcher ${ }^{*}$
}

The following is an edited transcript of interviews with Richard Buxbaum that took place over several weeks in October and November 2004, in Berkeley, California.

I.

GERMANY

\section{A. The Early Years}

$R B$ : My father was Jewish; my mother was a non-practicing Catholic. We were raised Jewish. In fact, in 1936, when my father recognized that something had to be done to get out, we were preparing to emigrate to Palestine. He went to pave the way, but he got very ill there and was hospitalized, which caused him to rethink that approach.

He had an odd career as a country doctor in Germany because after 1933 patients were not able to go to Jewish doctors on the basis of their participation in the national social security system. Most Jewish doctors, therefore, actually emigrated at that time because they had lost their livelihood, just as lawyers and university professors had lost theirs: because they were all civil servants. Some people in the village offered him a kind of mutual insurance company. He took that over and created his own socialized medicine system just for the village. Every family that joined-and essentially all did-paid one Reichsmark and twenty-five Pfennig per month, per family. I used to collect it occasionally. And he did that from ' 33 on.

Our village, Griesheim, also had the advantage of being a kind of "red village"-social democratic. There was not a strong local anti-Semitism, except in individual cases. There were people who made your life miserable, but it wasn't a generic thing. I had friends, for example, Gerald Gunther, who died

- Clinical Professor of Law, Boalt Hall School of Law, University of California, Berkeley. 
two years ago at Stanford, who had other experiences. He was born only about ten miles from my birthplace, Friedberg, in Usingen. That town turned out to be a real mess of ugly anti-Semitism and he got to feel it. He was fully Jewish, and on top of it, his father was the kosher butcher, and that was always a tense thing with the local populations.

You couldn't generalize, but we had a very easy time. For example, after going to the Jewish school in Darmstadt for first grade, I was put in second grade in the local public school, where there was mandatory religious instruction. The population was about two-thirds Catholic, one-third Lutheran. I was excused from religious instruction, of course, being a Jew (I was the only Jewish kid in the class). I couldn't go home because it was still school time, but I was allowed to go out in the yard and play by myself. I didn't think of that as exclusion, but as free time. Then, in my third year, because my father was planning to leave for the United States, we moved to Darmstadt and I attended its Jewish school. My father thought that the anonymity of the city was going to be helpful, but it was exactly the wrong move. Attending the Jewish school when I was in third grade caused me more trouble: the local kids who were next door at the school for young Pimpfe (young Nazis) would beat me up. I had to run the gauntlet daily.

\section{B. Post-war Germany}

$L F$ : You were raised in Germany. You came to the United States as a kid and were educated here. You earned an LL.M. degree at Boalt and then went back to Germany. How did that happen?

$R B$ : I was a draftee and went through basic training at Fort Bliss, Texas. Then I received a J.A.G. position. ${ }^{1}$ I had applied for it just before the draft and nothing happened, and later I found out it was because I had had somewhat leftwing Cornell activities. I ran for student council on a broad communist-left ticket and I founded a kind of whimsical club called "Republicans for Wallace" in '48, which was sort of a joke, although I did persuade my father to vote for Wallace, which he was so angry about afterwards. He said, "You realize Truman might have lost?"

Anyway, I got the commission and I went through the usual training and then I was lucky - this was in March of ' 54 - the army assigned me to Germany. I went over there in the summer of ' 54 . I was interviewed by the brigadier general, who was the Judge Advocate General of Europe, because at that time we were still in the occupation of Germany. He reviews my transcript: "Uh huh, military affairs, you were second"-this was a class of about eighty people"Very good. Well, we don't really have a position in that, but that's certainly something to keep in mind ... . Procurement,"-that was another course-“"Oh, very good. Well that's certainly some place to put you, but I don't think we have a need right now." Then, he gets to criminal procedure. "Ugh, not so good,

1. The Judge Advocate General's Corps is the legal division of the U.S. Army. 
eh?"-because I think I was 55 out of 80 in criminal procedure-“'Well, we do have a place for defense counsel." I always accused him afterwards, sort of semi-joking, that that's what he wanted, a patsy for defense counsel. I was appointed as court-martial defense. It was fantastic work.

Most of the work, first as defense counsel and then as prosecutor, was the normal range of crimes. But, here is an example that gets closer to the issue of returning to Germany. Because I spoke German as a native, I served for a while as a junior member of a team that was finishing the negotiations in Bonn of the NATO Status of Forces Agreement that was to go into effect when Germany turned independent in May ' 55 . Until ' 55 , Germany had no jurisdiction over Americans. But since this would change in May ' 55 , already in September ' 54 there was a lot of discussion about how the United States should address these relations. Also, I was the liaison to the German judicial system for our headquarters. I introduced our senior judge advocate corps to the German court system.

$L F$ : What was it like for you, socially and personally, to be in Germany?

$R B$ : It was made easy in two ways. First, my mother was not Jewish. So, through my relatives on her side, I certainly was less susceptible to automatically finding anti-Semitism. Already in ' 52 , my father and mother had come back to visit Germany. My father was very much like most German Jews: despite having lost everybody, he knew the difference between the people who had suffered themselves and those who had been perpetrators, even though every family had some of each on the whole. My mother's family, being a Catholic family, had been pretty immune. It also made a difference that my father had been close to my mother's family. Second, the village where my father practiced medicine was politically liberal. His ability to reconnect to that Germany was specific to those two elements. And, of course, I had the benefit of both those things. In personal terms, therefore, returning to Germany was marked by the fact that you always felt somewhat suspicious of people you hadn't known before the war.

For example, it was a known fact that the legal profession and the judiciary were among the worst in terms of being former Nazis, in the post-war period. There had been very little clean-up of old Nazis in the legal profession and you always were a little bit nervous as to who was who. There would be people with whom you got along fine, professionally, and then you learn six months later that they had been SS legal officers. And, of course, the same thing was still going on from ' 61 on. In other words, when I went back as a professor you'd be sitting at a table with someone and then later you learn he had been a Nazi. But, I also had a lot of academic and professional colleagues in '54, '55, who I knew were clean because some of our civilian attorneys in headquarters had stayed on after they were demobilized in '46. These colleagues were tremendous resources. They would advise me: "Stay away from him ..." or "You don't have to worry about him; he's good, clean, and he really did his best during the 
war."

When you were working in Germany at that time, you had to feel compromised by the presence of former Nazis. There was no way to function otherwise. You accepted it, although you had your nervousness and your anger.

Years later, one of the wonderful professors who helped set up the exchange program for the Ford Foundation for Berkeley, Gerhard Kegel, said about this time: "Look, it's a little like Shylock: There was no way in my view to tear out the bad part from this scene because it was a continuum from people who were against the regime, people who wished it would go away, people who were resigned to have to live within it, people who compromised with it, people who were happy to have a little advantage, people who were believers, and then people who were doers. So, all of that is just part of the fabric." What are you going to do if you don't have a Night of the Long Knives ${ }^{2}$ at the beginning? After it is over, you aren't going to have much luck with anything other than evolution. I must say that's sort of what happened.

When I was there in the mid-50s, the anti-Semitism was still pretty strong. That wasn't a kind of poison that you could quickly leach out with anything like an antidote. Thirty-year-olds in 1955 were fifteen in 1940. They were totally indoctrinated with anti-Semitism. Whether they were in the war or not, it took time for these attitudes to lessen. And, of course, the urban population of Germany, not the rural but the urban, was and saw itself as victims-the bombing was unbelievable.

$L F$ : How did the anti-Semitism manifest itself?

$R B$ : Ill ease with Jews. Somebody at that time wrote, "They'll never forgive us for what we did to them." And that's the best single way to put it. Now, "never forgive" is not so much literally that, but that they will never get over what they did. The ill ease was exhibited by a false philo-Semitism, false friendship, and false behavior. Whether it was "anti" wasn't so much the point; the point was that it was unresolved.

$L F:$ And you felt that?

$R B$ : Well, for example, many people would talk about their Jewish friend or friends, or those who were their colleagues before the war. Almost everybody had some "Jew" in this category; it was just standard. And of course, a large part of the population, let's not forget this, did have these relationships up into the ' 30 s and did feel the reality of this loss.

\section{The Second Generation}

Once you get to the late $60 \mathrm{~s}$, what are you going to do with people who were born in 1940 and who are now twenty eight years old? The more you deal with younger people, and of course by now, today, these younger people themselves are sixty five, the more you really have to ask yourself why would I

2. The Night of the Long Knives, between June 29 and June 30, 1934, saw Hitler eliminate many Nazi leaders whom he feared would someday challenge him for power. 
be ill at ease about this now?

The psychological need to suppress, repress, put aside, get to work, reconstruct, rebuild your psyche as a victim yourself, and so on-all of those things are mostly the problem of the first generation. This "inability to mourn" is what the Mitscherlisches termed it. They were a famous husband-wife team of psychologists who studied the immediate post-war German psyche and whose book was about the inability to mourn. That's sort of inevitable.

By the time of the second generation, the issue is how people who were bom from 1935 on deal with their parents' generation. It was very hard in many families. There was silence, taboos, outbreaks against the father, rebellion, and unconscious absorption of the father's retrogressive views, or mother's, but more often the father's. Those are the problems of the second generation. In a way, the ' 68 rebellion, at least for the German part of it, was sort of sons-versusfathers. There were those who had a strong need to break out of this shell and to batter themselves against the prior generation. Often, these individuals were members of the extreme left, but that's only one part of those who went to the other extreme to "fight against false philo-Semitism."

There was a famous debate around 1970 in the German $\mathrm{SDS}^{3}$ around the question: "How are we going to get over this stupid love of Jews?" Now, it was a provocative thing, but you can also see it. And of course, by 1970, after all the Palestinian miseries had begun to come to the attention of the world and to some in Europe, especially Germany, it was very easy for some to use that as an excuse to shed one's phony love of Israel. Of course, for others it was a dilemma and an agony. And all of that was nascent during my service years there. During this time, the Arab world was not understood as a society, so that the pioneers of Israel were considered heroic without any ambivalence. The Germans appreciated that, I would say, like everybody did. The pioneers of Indonesia also were considered heroic because they were anti-colonization. And, the pioneers of Yugoslavia were admired because they were a communist, anti-Soviet group. Those three countries absorbed a certain amount of energy from the left and that slowly, in various ways, was dissipated in the case of Israel.

\section{Experience with and Reflections on the Post-war Generations}

$L F$ : It seems that you have had a complicated and multi-dimensional relationship with your country of origin. What do you make of your own connections to Germany? What do you think about what we now call transitional justice and the ways in which theorists and advocates talk of the need for justice and accountability and closure for victims? Are these goals achievable? Is it better to remember or better to forget?

$R B$ : I personally think that an outside observer would make more of my connection to Germany than I feel is worth making. An awful lot is absent, old,

3. Students for a Democratic Society, a leftist organization of the era. 
and incidental. For example, my marriage to my former wife did not occur in Germany. She was a student here at Boalt. We met when she finished her graduate studies. I'm sure the fact that she was German had some bearing, but I met her in a very American context and it could have been somebody else who didn't have a German background.

The fact that I'm bilingual and retain German made it obvious and natural that I would have easier relations or different, somewhat more subtle, and ultimately deeper relations with the various German graduate students and with the various German professors who came here. And, we've had more than a random run of German colleagues here: Stephan Riesenfeld and Albert Ehrenzweig were on the faculty. And, in 1954, Dean Prosser decided to focus Boalt's international legal studies money (provided by the Ford Foundation) on that specific country, the country of their linguistic origin, and they decided to focus on this post-war reconnection. So, I walked into that here, but that certainly wasn't why I was hired, nor was it a basis for me coming. I came because it was a wonderful place.

I certainly have the sense that I know a lot about the German society, especially the academic society, because of the chances to develop these relations. The fact that I can speak German makes Germany the most likely place to go as a visiting scholar because I can lecture in German. Those things evolve and they end up in retrospect being a fairly significant element of your professional life, and to some extent, your personal life.

The way that connects to the history of the Third Reich is a little bit complex. We were out before really bad things happened to us. Also, I was too young and I took my emotional marching orders from my parents. How they saw it and how they reacted became a very big part about how I would react to it. In the post-war period, the fact that I come from a mixed family where I had insights into what a non-Jewish German family or family groups were like was special. I don't have a fully "Jewish" reaction, although I have to make one important point here: there are people of my generation-and even children of those people-who never grew up in Germany, but who will not set foot in Germany to this day. But, even among Jews, I would not say that this is a majority.

Many of those who had been able to leave returned as visitors (but very few permanently). The wish to be reengaged may have come from many different motives. But, even some of those who had lost most of their family, who were Jewish fully as I was not, reengaged with Germany. For many of them, that was a very important political reengagement, particularly for the ones who were adults when the Holocaust happened. It's almost a mixture of the depth of religious and ethnic bonding and of class. If you come from an academic class, you tend to develop a loyalty to a set of principles and values which may to some degree trump other more ethnically, linguistically, or religiously related issues.

I remember very well my Berkeley colleague, Reinhard Bendix, a wonderful man, who was a young adult when he escaped Germany as a Jew, and 
suffered much more than I did. In his autobiography, which is entitled From Berlin to Berkeley, he ends with an interesting observation: "I belong to a university. I'm not German, I'm not American, I'm not Jewish, I'm a professor. My true community is the university." This was not facetious. He made a very interesting point, subtle, but also very dangerous because it's open to misperception. Nevertheless, there is something to your socialization in the very particular atmosphere and kind of value system that $I$ have spent my professional adult life in which makes that difference.

$L F$ : On that continuum, would you say that your identity then is primarily as an academic?

$R B$ : And as an American, I think. I have this very easy comfort granted me in Germany. I am a privileged visitor there because of speaking German, so I am kind of carried on satin pillows. I get the benefit of both worlds. I play the American, but I get inside the German discourse in a way that people privilege. So, it is a very ego-stroking situation, in fact.

$L F$ : What are your thoughts and experiences around what can be described as the project of transitional justice? In Germany, transitional justice was the most advanced in many ways. There were trials and extensive reparations. In fact, the reparations project is ongoing and involves not just the state, but private actors returning property, and so forth.

$R B$ : You know, we are now sixty years past the end of that horror. The bulk of the generations that we live among really have only, even by their consciousness-maybe by being Jewish-a historical relationship to that time. And it is therefore somewhat a constructed relationship.

My experience, simply going by my generation, is that in the immediate post-war years the Germans were able to characterize themselves, to some extent legitimately, as victims. Their own dealing with the specific horrors of what their own people did in terms of both the aggressive war and the slaughters added to this sense of victimization, which was also fueled by the post-war hardships.

There's a slow evolving out of that as a younger generation comes along, the ' 68 generation. There was never an early internalization of a collective responsibility or guilt, but there was a collective shame or a collective recognition. There was never a sense: "We were the doers-even if we were duped." I think it is relatively rare that people will figure this out on their own when the ones to whom they did it are no longer there. It isn't like in South Africa where both groups continued to live together. The Germans or the Nazis did their job too well and Germans and German Jews didn't have to live together afterwards. What's happened with the new multicultural situation in Germany, the influx of other people, is a new phenomenon that can't resolve the tensions and the history of what happened to Jews. You also could not expect the German World War II experience to permanently lead their modern reactions to these new migrations into a uniquely different relationship than is the case in other countries, like Poland, or even Italy, where you have xenophobic difficulties. 
$L F$ : Do you think there's something that could have been done that would have stimulated this internalization of what you called collective shame, or was that an unrealizable aspiration?

$R B$ : Well, you can look at it in two ways. One is that the circumstances of the post-war years-the anti-communist bipolarization-prevented that and therefore it's a moot question. Or, you can take a more general perspective and ask is it ever feasible? Are you still the same society evolving out of a shameful period by your own, on your own, or are you a conquered people who are being "helped" to evolve out of a shameful period through the heavy hand of the conqueror, even benignly, acting for you? That's the first question. The second is do you still have the same two groups that have to live with each other? And that, of course, is the tragic situation in Germany. On the whole, Germans were left without having to face the people against whom they, or rather some of them, had committed these atrocities. Those are the two big differences I think.

II.

THE LEGAL ACADEMY

$L F$ : What led you to law school?

$R B$ : Well, I was the oldest and the lightest sleeper and I was the one who was always awakened by my father to help him. Remember these were country practices, particularly out in Bombay, New York, where we first lived. Whenever something happened, I was the one who got up and went to the door. I felt that a doctor's life was a very hard life and I didn't like it.

I was much more attracted to the easy job of playing with words. That was more reasonable. My father didn't like it that I didn't attend medical school. Luckily, my brother did, so that took the heat off. My father thought medicine was a noble profession and he hated lawyers, he just hated lawyers. He always thought they were out to cheat people.

$L F$ : Did you consider anything else?

RB: I had a double major in Economics and Slavic Literature. I didn't give a damn about economics: it was boring. But the Russian literature was wonderful. Nabokov came to Cornell in the fall of ' 48 and I was eligible to enroll in his Russian language seminar on Russian literature. We were only eight people, so it was very nice. However, I didn't think a non-Russian had much of a shot at a career in it, since at that time most of the Russian literature professors were Russian emigrants.

$L F$ : What was law school like?

$R B$ : I did very well. Once we got our first semester grades, I was amazed that I was very high and I didn't have any clue as to why. You would be surprised about how much you like something if you look like you are good at it!

First semester was not great, although we did have a wonderful teacher, Rudolf Schlesinger. He was really an inspiring teacher-he had the energy and the crackle. But, the other classes consisted of pretty doctrinal teaching. The 
professors certainly hadn't heard of the kind of contextual, social science approach we now have. They taught policy in the "pre-toolkit" sense; they just knew it was good to have a progressive income tax.

$L F$ : How many women were in your class?

$R B$ : We had six women in a class of 137 . I remember that exactly.

$L F$ : What were your interests during law school?

$R B$ : Two things really: corporation law and international transactions. I was interested in corporations from the beginning. Rudy Schlesinger got me interested in international transactions. He was just brilliant at getting you to think of the world of new transactions in the postwar period. I got really quite excited about that.

When I graduated I had an offer to be a teaching associate at Boalt. Just when I was more or less close to leaving for California, my draft board said: "You can't do it"- I had to enroll in a degree program. I wrote Dean Prosser and he said: "Well, we have an LL.M. program. Why don't you come and do that?" That's all the admissions there was. Democratic centralism, you know? The only problem was that I was going to be paid $\$ 4,800$ a year for the teaching associate position and instead I was paid $\$ 1,200$ for the LL.M. program. I had to take jobs when I got out here. But, the tuition was nothing: it was $\$ 200$ for the year or something, so it was doable.

$L F$ : What was the subject of your LL.M. thesis?

$R B$ : Preferred stock, corporation law. Now, that was a weird, a weird thing. I, myself, have tried to think back on it. I liked corporation law at Cornell, although we had a terrible teacher. The only thing I remembered about that class was Professor Larson looking up saying: "Oh, my God! It's raining and my top's down!" and running out the door. That's the sum total of what I remember from corporation law!

When I got to Boalt, there were two major strands in corporation law. One was the comparative angle, and we had people like Ehrenzweig and Riesenfeld. For me, it was wonderful. Here were émigrés who already had their education in Germany and they kind of took me under their wing as a young kid of German-Jewish background. They liked the fact that I could schmooze with them in German.

I was looking for a thesis topic in the fall and Dick Jennings said: "Well, you seem to like this corporate finance." He was beginning to work on preferred stock, which he hadn't apparently done much of and he said: "You know that would be a good topic to go into at more depth, but you'd have to really know what the practices are with it." And, Steve Riesenfeld already had been very influential on me in terms of thinking I needed to go to "bedrock" documents. He told me: "You're not a scholar and you're not a legally trained person if you rely on secondary sources; and it doesn't matter what language, and it doesn't matter what material."

I remember that he had done his own dissertation in 1931 or so with Arthur 
Nussbaum on mutual insurance companies. What he had done was to actually read the statutes-the charters-of dozens and dozens of mutual insurance companies in order to know exactly how they formed their relationship with their members. When Jennings said that the way to do this project is to know what is being done in preferred stocks and not just by reading the cases, I got the idea of setting up a questionnaire. I wrote to an underwriting firm in New York, Spencer \& Trask, asking them, because they specialized in preferred stock underwriting, if they would send me the actual certificates-the board of director resolutions of preferred stock issuance-which are the preferences and privileges of the particular issue of stock. I got about one hundred and fifty of those and I analyzed them.

My thesis, and then an article in the California Law Review, analyzed the case law and saw that there were pathologies, but also looked at the actual drafting. That's why it is called "Law and Draftsmanship." It's weird, but that's the very first real thing I wrote, other than student notes, and it's the one thing that still gets quoted because it's still somewhat relevant. The Delaware court still uses it. I'd like to think that something I wrote in a more mature way is also interesting, but the fact is that my thesis was more practical.

On the other hand, I really got interested in this comparative jurisprudence business. You know, Albert Ehrenzweig was just wonderful in that. And then the other guy who was very, very helpful and is still here is Adrian Kragen. ${ }^{4} \mathrm{He}$ is a tax person, but he taught antitrust and I took it and I was just fascinated with this government-business interaction stuff. I just loved that. I think it was from that year that I decided if I could get back and be an academic, I would love it. But, it didn't look to be in my future. I was still waiting to join the Army and I was sort of an upstate kid. My image had been to be a small town practitioner. My father was a small town doctor, rural doctor, and I really did think that was a good way to spend your professional life. So, I sort of loved this idea of teaching but I didn't think it was a real idea.

I went on the market after I returned from the Army and had practiced for a few years. Rudy Schlesinger talked with Frank Newman-this is where the old boy network really functioned in the old days! The old gang who had been teachers already in ' $52 \mathrm{knew}$ me and liked me. I had done a good job on my thesis, Jennings was very pleased, and Boalt needed a second corporation and corporate finance person. They had nobody but Jennings.

Bill Prosser, kind of an eccentric character, held a dinner for me during the three or four days I was out here in January. It was the typical faculty dinner of the time. The wives did the work; his wife, Eleanor, was the hostess. A black woman, a Negro woman if I'm to be true to the vocabulary then, a very nice upper middle aged woman with a black dress and white apron served us. She

4. Professor Kragen passed away on March 25, 2005. 
was not a servant-nobody had servants — but she was the traveling domestic. I still remember being intrigued by the fact that most of the women who came to dinner greeted her by name, so they knew her from their own dinners! And we ate as fast as I had ever eaten in my life. I was barely finished with the main course and Prosser says: "We'll take the dessert downstairs in the family room." He just gets up and everybody leaves. I don't think anybody was finished.

Prosser sits down at the piano and starts tinkling away at it. Mike Heyman was near the piano and Prosser beckons me over and says: "I don't suppose you read music do you?" I said: "I read music." He said: "Try this." You know, I'm flabbergasted. I still remember the tune. I think it was from The Bohemian Girl, a $19^{\text {th }}$-century musical: "I Dreamt That I Dwelt in Marble Halls." It was high for me, but I sang it at the piano. And when we were done with it, he turns to Heyman and he honestly says: "Ok, I think he'll do."

I learned from Mike that Prosser was responsible every year for the music revues at the AALS ${ }^{5}$ annual meeting. He had inherited that apparently from Paige Keeton. Prosser had raised a storm with Mike that he was damned if they were going to appoint another man to the faculty who couldn't help him set up the music revue. Now, obviously it was not a sufficient condition to get hired, but I honestly believe it was a necessary condition.

There were four of us hired that year: Bob Cole and I, Preble Stolz, who sadly died so early, and John Jackson, who left as soon as he got tenure to go to Michigan and who has specialized ever since in the World Trade Organization and the GATT and has made a terrific specialty out of that. Preble, Bob and I were the three who continued through the years and were buddies. And we all got tenure the same year. I mean, in those days tenure track was not more than three or four years: we were tenured each with an article or two.

$L F$ : What do you think about the changes in the legal academy during your teaching career?

$R B$ : I'm a professional-type law professor in the sense that I think we should write more for the profession than for our closed circle of academics. On the other hand, I do really appreciate what social science input, especially economic, offers us professionally. It's always been a bit of a dilemma. I can read the stuff-I appreciate it, I use it-but I don't produce it.

I still don't know how I feel about this full graduate school concept that we all now at the best law schools feel we must be. I do think it has the disadvantage of creating writing for each other. At the top, especially in economic analysis, this writing has powerfully influenced the courts and legislatures, but it is a derivative influence. The larger movements towards economic liberalism, the Reagan revolution, the Thatcher revolution, were not generated by Easterbrook and Posner, right? Even if they provide a good deal of the scholarly grit that helps justify and maybe even to some degree advance these agendas, these agendas are not generated by the academy. The counter-

5. The Association of American Law Schools. 
forces of the critical legal studies movement and so forth are also part of that larger societal context.

I think we are coming into a second generation where the range of this additional academic training is broader-psychology, history-and therefore the inputs into policy discussions are less "one-legged." But, I still feel that there is a certain balance that could be struck in terms of service to the profession. This professional or purely doctrinal component has been left to the second-rate schools, second-rate law reviews, third-rate even.

The new legal scholars in the United States come to all of these faculties with these "tool kits" of economic analysis. We have seen an increase in the number of powerful mechanics skilled in the art, but have not necessarily seen a large increase in the number of inventors. I don't find as much imaginative push among these people as I wish there were because they are too wedded to what they can do best. I don't think that except for a very few of them that what they can do best is necessarily pushing the envelope, breaking bonds; and that is an issue for me. Mind you, I'm not speaking about Boalt-present company is definitely excepted.

There is both the professional aspect and the issue of when does real innovation happen. You are not going to expect a hundred breakthrough people; if you have five, you're lucky. You get imaginative people like Cass Sunstein, like Posner. Posner is an inventor because in addition to his analytic prestige that he has created for the academy, he has a powerful mind. One never expects more than one percent to do that, but then there are second-level imaginative talents and it is there that we have a little bit of a problem. Now, there was plenty of bad academic writing when you were aiming at the profession, too, so it isn't one or the other. It would be foolish to deny that overall there is an improvement--that would be denying the possibility of progress, right?

$L F$ : When you look back on your tenure here as a faculty member, what are the accomplishments of which you are most proud?

$R B$ : I think having a concern with the development of students and their careers. I really don't see the point of bashing students. I think I've been a good professor if you take the combination of teaching, research and service. I don't think I've been a very good professor in teaching and research. And service is more a matter for me of outlets for energy and escaping from the humdrum part of research. I'm not a top teacher. I'm not clear enough, and I wander. The Eisenberg model ${ }^{6}$ is one that $I$ will always aspire to, but never reach. In research, I think I've done decent research, and had some mid-level ideas. I'm not being negative about it; I'm just saying I did my job. I think I was a reasonably good citizen and part of it is being engaged in my desires.

6. Professor Melvin Eisenberg. 
$L F$ : What are the primary changes you have seen in the legal academy?

$R B$ : I think the teaching is the main change. The addition of clinical teaching, which we resisted, in fact, for longer than most peer faculties did, is a big change. For the rest of the curriculum, we are still stuck in similar boxes. It is just amazing to me how fifty years go by, and any argument that you shouldn't teach torts and contracts separately just doesn't apply. But clinical teaching is different.

In terms of research, I do think this dearth in producing practical research — because we are aiming to be another graduate faculty, and using the ethos of social science departments and their visions of research, particularly economics-is increasing. But there are other social science disciplines that take quite different methodologies and more of those are being reflected here too. I do think we are not likely to go back in the near future to doctrinal work or to be of significant aid to the profession's practitioners in a way that a good law school fifty years ago thought it was. We've divorced ourselves to a considerable degree from the image which a medical school might have; that is, that even if you want to do path-breaking research, you are still training the professionals and a lot of your focus should be on that. I don't think we see the profession anymore as our principal target of service. I think we see ourselves in our academic self-reflexive circles as being the principal target of our attention.

$L F$ : What do you think of Dean Edley's vision of the relationship between the academy, problem-solving for the real world, and research centers as the new model for the law school?

$R B$ : I think it's going to be interesting and difficult. We've had here the Earl Warren Legal Institute, which once I thought could be a center for service of various types of groups. We had a short-lived national center for financial services. But, we have never been able to get large bodies of our colleagues to buy into those objectives and to shift their way of working to the goals of such service groups. I will be very interested to see whether BCLBE ${ }^{7}$ becomes an example of service to the business side of society. I don't mean business as such, but service to the economy in its organized form. The goal for these centers starts as being a mix of some wish for more relation to the real world and some expectation that the real world would want us to care about its wishes. It may be good for students. The Berkeley Center for Law and Technology has found a reasonably good medium in that regard. But, I don't think it's easy to move the individual academic into this kind of team with an external focus work. We'll see. Perhaps having more colleagues whose social-science background leads them to teamwork will help in this specific regard.

7. The new U.C. Berkeley Center for Law, Business, and the Economy. 
III.

\section{SOCIAL ENGAGEMENT}

$R B$ : I was involved in litigation in three areas: the Free Speech Movement, protests against the Vietnam War, and the affirmative action strike. All of those involved criminal and civil cases.

$L F$ : What drew you to these areas?

$R B$ : Well, part of it was that I was a lefty. I was a socialist in the classic socialist terms when I was an undergraduate (remember this is 1946). I certainly was on the left at Cornell, and in the Army too. I was down in El Paso, Texas, during basic training. That's a western town, not a southern town, but because it's Texas, there was segregation. The restaurants, essentially by law, were segregated.

I had the luck to be part of a northern platoon; in fact, the only one down there at that time. We were like a cuckoo's egg in another bird's nest. When we first got Sunday passes to go into El Paso, we never went with less than six people together because we would get into fights. Among our group were some blacks and if we went to go eat, we'd all go together. I remember the first restaurant we went to, there were about eight of us, and the waiter said: "I can't serve a colored man here." And I remember saying: "Well then, you can't serve any of us, it's your choice." He chickened out and we all went in. From then on, even those who weren't particularly political, got into the zest of this. We'd go to bars and always be sure that we were a mixed group because we wanted to make a statement that serving all of us, black and white, was going to be allowed.

The last stages of the Free Speech trial and the sentencing stretched out and stretched out and overlapped with the beginnings of our reactions against the engagement in Vietnam. I certainly wasn't in a minority of one in being antiVietnam War. That was much more of almost a mainstream reaction. I would say the majority of the Berkeley faculty, including the law faculty, was fairly anti-war. We were actively engaged to say publicly that these were terribly mistaken directions that we were taking.

Some of the students who had been engaged in the early days of the Free Speech Movement were now major players on the campus in creating "stop the draft" movements. There were reactions against this from the Board of Supervisors of Alameda County, local police, and so forth, who tried to get injunctions against campus meetings. I was counsel a few times for the ASUC. ${ }^{8}$ There was one action in federal court before Chief Judge Harris, in which we sued to dissolve a temporary injunction against holding marches.

Also, I was involved in some of the conscientious objector (CO) litigation, more as a witness in court regarding international law than as a litigator. But we

8. The Associated Students of the University of California. 
represented some Catholics who had a very hard time with $\mathrm{CO}$ status because their doctrines did not contain anything as simple as those of the Quakers. When Catholics tried to avoid going to the Army by claiming CO status, those were tough cases and they would get prosecuted.

Starting in ' 69 , we had this major effort to get affirmative action for student admission on campus and there I was involved quite consciously and intentionally. In the summer, I think of ' 69 and some of ' 70 , I was very much involved in that kind of work because there was a lot of campus turmoil and there were a lot of criminal cases because students would constantly be charged with assault, trespass and so on.

I thought affirmative action was wonderful. I would say a good half of the faculty found it quite enriching. The other half accepted it, and up to maybe three or four, at the most, carefully tried nonetheless to hold to the position they saw as anti-affirmative action. But, the major sense here was pro. For example, you have to remember that one of the main amicus briefs in the Bakke case, ${ }^{9}$ a very important brief for the AAUP, ${ }^{10}$ was authored by our colleagues David Feller and Paul Mishkin.

$L F$ : How did affirmative action play out in the day-to-day interactions in the classroom?

$R B$ : Some faculty members had a few in their class who were not up to the level of the other groups and I would say that might have just bubbled along, but got quietly accepted. There were very significant battles inside Boalt when student movements pushed for a stronger, more engaged, activist affirmative action. Students led campaigns in front of the campus, entering classes, even rarely more direct action like pouring glue into the locks of the door so they couldn't be opened, and so forth.

After the mid-1970s, affirmative action got settled in. Up to the early $80 \mathrm{~s}$, there were occasional conflicts within the school about the degree of changeusually pressed by students for more change. Once in a while, we had to bring in outside lawyers, black lawyers, to create some sense of stability, but also to push us faculty.

$L F$ : What is your sense of the faculty reaction to the dismantlement of affirmative action at Boalt?

$R B$ : We all looked at that with a lot of anger. If there were two or three people who welcomed it that would be a lot. That there were fifteen or so who acquiesced in it after thinking it through and deciding there was nothing to do, is also true. But, there were certainly also ten or fifteen who were constantly looking at ways to push the envelope. And the silence at Boalt, I think it has been read as being a sense of acquiescence that I think isn't quite fair. It wasn't that acquiescent.

9. Regents of the University of Califomia v. Bakke, 438 U.S. 265 (1978).

10. The American Association of University Professors. 
$L F$ : Do you view the two spheres-your scholarship and your social engagement-as two separate arenas?

$R B$ : No, I think that's kind of reductionist. I don't know that your intellectual or curricular interests have to be all of a piece. I don't think anything I have done in terms of teaching or writing, say in corporation law, would not be accepted by somebody who wants to be an activist. I have taught corporation law with some sense for the role of the large enterprises of power $v i s-\grave{a}$-vis society and the polity and the culture. It just happened, also partly accidentally, that I got into it early because of interesting intellectual interests and then because that's the field I got hired to teach. You develop an agenda in terms of writing. I've never thought of the two as being bifurcated in that sense. I think that's more a young student group's sense that it's got to be one or the other. You know, that you are either "them or us" in these contexts, and that doesn't bother me. 